\title{
H.F. Verwoerd's student years - cradle of his political career and thought
}

\author{
J.D. Froneman \\ School of Communication and Information Studies \\ Potchefstroom University for CHE \\ POTCHEFSTROOM \\ E-mail: komjdf@puknet.puk.ac.za \\ Abstract \\ H.F. Verwoerd's student years - cradle of his political career and thought \\ This article briefly describes student life in Stellenbosch during the period \\ 1919-1924 when the young H.F. Verwoerd was immersed in a general \\ Christian ethos and atmosphere of Afrikaner nationalism which he \\ articulated with fervour. \\ In view thereof, the notion put forward by Miller (1993), viz. that South \\ Afnica's sixth prime minister changed his political beliefs substantially when \\ he became the editor of Die Transvaler in 1937 is rejected. It is found that \\ the basic views Verwoerd held as a student were generally consistent with \\ those he held in later life. It is accepted, though, that some of his views \\ were adapted and inconsistencies could possibly be identified in some of \\ his views. \\ Unlike Miller's analysis and conclusions, Venter's (1999) analysis of \\ Verwoerd's political thought is found to be remarkably consistent with the \\ views and activities of Verwoerd the student activist. Consequently, this \\ article argues that the context and nature of the political views he held as a \\ student at Stellenbosch help significantly to explain Venwoerd's later \\ positions as lecturer, editor and politician, even if he did not personally \\ subscribe to every view expressed by the Students' Representative Council \\ he was part of and chaired.
}

\section{Introduction}

In her study of the early (academic) career of H.F. Verwoerd, Miller (1993) correctly points out that biographers have tended to skim over the early years of South Africa's sixth prime minister. With reference to Verwoerd's early working years (as university lecturer), Miller's study 
questions the assumption that Verwoerd was a life-long, consistent Afrikaner nationalist. Verwoerd the lecturer was, according to Miller (1993:4) "neither a strident Afrikaner nationalist nor a doctrinaire white supremacist". He was, however, clearly "ambitious, energetic, pragmatic, and opportunistic". In view of Verwoerd's relatively "liberal" views as lecturer, Miller identifies a "transformation" in Verwoerd's attitudes after he had become editor-in-chief in 1937 of Die Transvaler, a new Afrikaner nationalist daily. But in suggesting that Verwoerd had a change of heart, becoming a rigid ideologue for pragmatist and opportunist reasons aimed at fostering his political career, Miller may well have made the same mistake as the said biographers whose "historical examinations slide quickly over his early life" (Miller, 1993:2).

In his article on Verwoerd, Venter $(1999: 416,417,426,427)$ refers, albeit briefly, to Verwoerd's student years in his analysis of the foundations of the former prime minister's political thought. He concludes that Verwoerd the politician placed a high premium on "understanding", rational thought, the superiority of Western culture, the removal of friction and the imperative placed on all individuals to assist in the upliftment of his/her own ethnic group. Could this be traced back to Verwoerd's student years?

In order to better understand, assess or expand on the important aspects of Miller and Venter's findings, this article therefore examines Verwoerd's student years at the University of Stellenbosch. Special emphasis is placed on the general context within which the bright young Verwoerd developed from a freshman into a dominant Students' Representative Council (SRC) chairman. Greater understanding is sought of the foundations and consistency of Verwoerd's political views - views which are indeed of importance in understanding the mind of the so-called architect of apartheid.

\section{Context of Verwoerd's student life}

When Verwoerd arrived at Stellenbosch in 1919, the University of Stellenbosch was at the beginning of a new era, having shed its Victoria College name, status and symbolism the previous year. It had required a concerted effort by Dr. D.F. Malan and other Western Cape Afrikaners to eventually secure Stellenbosch's status as a fully-fledged Afrikaans university.

The founding of this volksuniversiteit ("people's university") followed in the wake of the founding of the National Party (1914) under Gen. J.B.M. Hertzog (a former Stellenbosch student) and Die Burger (1915) as mouthpiece of Afrikaner nationalism under the editorship of another exVictorian, Dr. D.F. Malan (Muller, 1990:119-164). These institutions, 
which were to play crucial roles in the development of 20th century Afrikaner nationalism, formed the cornerstones in a growing constellation of Afrikaner institutions (Booyens, 1969:185-189; Du Toit \& Venter, 1966:63, 65)

The Afrikaner was slowly overcoming the economic and psychological devastation of the Anglo-Boer War (1899-1902) in which some 34000 Afrikaners died -27927 of which were women and children inmates of British concentration camps (Wiid, 1973:434,435; Davenport, 1986:217). At the same time the shockwaves of the 1914 Rebellion of Afrikaners against an Afrikaner-led government were still felt - even in the somewhat secluded university town of Stellenbosch, where students expressed their support for Afrikaner rebels by signing a petition (Rothman et al., 1924:26).

By 1919 the strong anti-government feelings evoked by World War I among many Afrikaners had subsided somewhat, but in its place a more assertive nationalism aimed at securing the survival for the Afrikaner was steadily growing - to such an extent that, after a public meeting in Cape Town, the newly elected prime minister, Gen. Jan Smuts, complained to his wife that young Afrikaners had all turned rebellious and nationalist (Meiring, 1974:96).

Meanwhile, the idealistic nationalism of the small1, closely-knit Stellenbosch student community was stimulated further by influential lecturers and visiting speakers. Verwoerd's first year at Stellenbosch saw the appointment of the first professor of Afrikaans, J.J. Smith, as well as Jan F.E. Celliers, the foremost patriotic Afrikaans poet of the time, to the post of extraordinary professor of "Dutch-Afrikaans Literature and Aesthetics" (SRC minutes, 1918-08-13; Du Toit, 1966:72-74). Students were inspired by these and other professors, notably Prof. E.C. Pienaar, an oudstryder (ex-soldier) of the Anglo-Boer War and outspoken nationalist who believed that Afrikaners had to discover their own worth and inner strength via their mother tongue (Malherbe, 1977:34,112).

Visiting speakers included the leader of the Cape National Party and editor of Die Burger, Dr. D.F. Malan, as well as the ever popular champion of Afrikaans language rights, C.J. Langenhoven, whose patriotic plays were performed by Stellenbosch students in many rural town halls (Malherbe, 1979:402; Kapp, 1975:80; Hugo, 1966:332; Burgers, 1939:89, 126). In so doing, the students participated in spreading the National Party's message (Kannemeyer, 1995:383). 
But if Langenhoven's regular visits to Stellenbosch unfailingly ensured packed halls, the visit by three "rebel generals" (Muller, Conroy and Kemp) and a "rebel commandant" (De Wet) was a highlight of student life in 1920, Verwoerd's second year (Du Toit, 1966:179). The students gave the Boer heroes a tumultuous reception and aligned themselves with the rebellion of 1914 (Stellenbosch University Magazine [SUM], June 1920).

Likewise, a concert tour by the Flemish singer Hullebroeck in the summer of 1920-1921 was of particular importance. His visit to Stellenbosch and other towns and cities helped to open Afrikaners' eyes and ears to the power of nationalist poetry and songs, including this rousing Jan F.E. Celliers poem:

Jukke mag vir slawe wees

Manneharte ken geen vrees

Duld geen band vir lyf en gees

Vryheid! Vryheid! Vryheid!?

In the absence of radio and television, students relied on Die Burger for daily news and the interpretation of political events. This was supplemented by magazines such as Die Brandwag (which was published since 1910) and Die Huisgenoot, a monthly published since 1916 under editorship of Stellenbosch academic Prof. J.J. Smith, with the specific aim of promoting Afrikaans language and culture (Muller, 1990:254-256, 274). By 1923 the magazine, which was significantly also dubbed the "people's university"', was well-established and became a weekly, thereby increasing its potential influence. Other magazines, e.g. Die Boerevrou, had the same ideals as Die Huisgenoot, but were aimed specifically at Afrikaner women readers (Slabbert, 1992).

Verwoerd and his fellow students at Stellenbosch were therefore shaped by a number of strong nationalist influences. It comes as no surprise that Stellenbosch increasingly became known as the hotbed of Afrikaner nationalism, as is confirmed by an examination of the Stellenbosch students' political and cultural activities in the period 1919-1924. Simultaneously, Verwoerd emerged as an articulate leader of extraordinary charisma and forcefulness.

Yokes may be for slaves

Strong hearts know no fear

Accept no chains for body or soul

Freedom! Freedom! Freedom! (freely translated) 


\section{Afrikaner nationalism of Stellenbosch students}

Stellenbosch students communicated their Afrikaner nationalism and loyalty to Afrikanerdom in a number of ways, notably through the popular culture of the time. This included volksteater (people's theatre), the activities of the crucially important debating societies and organised singing in Afrikaans, mass meetings, posters, petitions, protest marches, motions accepted by the Students' Representative Council and publications (Froneman, 1995:119).

The students expressed specific and enthusiastic public support for Hertzog's National Party, before and after the party came to power in 1924 (Pretorius, 1959:114, 115; Die Burger, 1924-06-19). The support enjoyed by the NP among the students was reflected, inter alia, in their views on race, language and South Africa's relationship with Britain - the key issues of the time.

Segregation was specifically accepted by the SRC (of which Verwoerd was a member) as "the only solution" to the "race problem" (SUM, June 1921). Sharing the local cinema theatre with people of colour was therefore strongly rejected by the SRC at its meeting on April 61921. Although there were a few dissenting voices among students, the SRC clearly reflected the view of the majority of students (Stellenbosch Student [SS], June 1924). And at the same meeting where Verwoerd was appointed chairman for the 1922-1923 term, the SRC confidently and unanimously rejected a suggestion that a visiting "American negro" address the students at a public meeting (SRC, 1922-08-17). There is no indication whatsoever that Verwoerd held views contrary to those of the majority. Given the closely-knit fabric of Stellenbosch student life at the time, it is inconceivable that Verwoerd would have become chairman of the SRC if he differed from the majority on such a crucial issue as race. This argument also applies to the other issues addressed in this article.

Although important, racial politics was not of overriding importance. Language and cultural issues were even more crucial at the time. The Stellenbosch students could be found at the forefront agitating for the acceptance of Afrikaans as the true language of the Afrikaner, a language that was fit for church and state, academic life and everyday discourse. This brought the students into conflict with conservative Afrikaners (notably theologians) who were clinging to Dutch for their own good reasons (cf. Froneman, 1995:90).

The students successfully requested the creation of a chair in Afrikaans and urged the university to accept Afrikaans as the only medium of instruction (SRC, 1919-09-07; 1920-03-03). This insistence was understandable in view of the fact that some 6 out of the total of 24 
H.F. Verwoerd's student years - cradle of his political career and thought

professors were still relics of a previous era and who only lectured in English (Hugo, 1966:347). The SRC also requested the local congregation of the NG Kerk (Dutch Reformed Church) to allow dominees (pastors) to deliver sermons in Afrikaans instead of Dutch, if they so wished (SRC, 1920-09-07). In his 1922-1923 report as SRC chairman, Verwoerd made a point of mentioning the students' bitter disappointment and sense of being wronged by the church council which was not sympathetic to Afrikaans (SS, March 1924; cf. SUM, Nov. 1923). As such he identified strongly with the language nationalism which permeated student life at Stellenbosch. The issue of the use of Afrikaans from the pulpit precipitated a long battle between students and church council, which was only dissolved when the students were allowed to form a separate congregation.

Verwoerd also made an unequivocal stand as SRC chairman in requesting the conductor of the Cape Town Symphony Orchestra to refrain from playing "God Save the Queen" at Stellenbosch performances. Verwoerd stated (in English):

I am very glad to say that your concerts are thoroughly appreciated by us, but the playing of the National Anthem does not meet with our approval and I am convinced that the majority of the audience desires to see it discontinued (Scholtz, 1974:21).

The conductor acceded to this request, thus affording the future prime minister, who was to lead South Africa to become a republic, an early and telling political victory.

The students' interest in music encompassed more than merely passively enjoying good classical music. They were not known for their spontaneous singing, but the inception in 1918 of a full-blooded rugby intervarsity with the University of Cape Town (which was founded on the same day as the University of Stellenbosch), as well as a "tide of national idealism" which swept over Stellenbosch in the post-war years, contributed in igniting an interest in Afrikaans music (Gericke, 1977:2, 25; Hugo, 1966:330). Patriotic and student songs were practised on Friday afternoons under the auspices of the SRC. But as Afrikaans was in many ways still in its infancy, the SRC appointed a commission to compile a songbook of patriotic, popular and football songs. The reason was spelt out in no uncertain terms: "we must be Afrikaans and patriotic" (SUM April 1920). This sentiment correlated perfectly with Verwoerd's views on Afrikaans and patriotism.

In the winter of 1920 a group of pioneer Stellenbosch students toured the platteland (rural areas) bringing Afrikaans and Dutch music and literature to Afrikaners who previously never had the opportunity to hear and enjoy 
performances of this nature (Eyssen, 1964; Van Blerk, 1986:738). The tour was not only of huge cultural value to the rural Afrikaner, but also produced a tidy profit of 350 pounds, which, significantly, was sent to German orphans suffering from tuberculosis. This underlined the direct link between the students' cultural activities and their socio-political agenda.

The 700-odd students at Stellenbosch also contributed financially from their meagre allowances to other causes deemed worthy. They supported the Helpmekaar fund (which helped the rebel leaders to pay their fines), which was promoted so vigorously by Malan's newspaper, Die Burger, and sent the large sum of 600 pounds to help the "suffering women and children of Central Europe" (SUM, June 1920). The SRC, chaired by Verwoerd, furthermore gave its blessing to fund-raising by the Helpmekaar movement among the students and gave "moral support" for fund-raising among students for the less privileged (SRC, 1923-05-18). Through the years the students also expressed their solidarity with the Afrikaner nationalist cause by contributing to the erection costs of monuments for Afrikaner heroes (SUM, June 1918; SRC, 1919-05-06). This was also the case during Verwoerd's tenure as SRC chairman (SS, Nov. 1923).

Of some significance was the seemingly trivial "anti-chocolate law" which forbade presenting women students with a box of chocolates when going to the cinema. This step was, according to Hugo (1966:342) indicative of "a lively sympathy for the less affluent student who could not afford this kind of luxury. The 'chocolate law' was therefore an expression of the strong group cohesion ...". Was Verwoerd supportive of the "antichocolate law"? Unfortunately there is no direct evidence to prove or disprove such an assumption, but it did correlate with his sentiments on expressing solidarity with less fortunate volksgenote.

Whatever the students did in expressing solidarity with people in need, or in building a distinct Afrikaner culture, Verwoerd was difficult to satisfy. He repeatedly urged his fellow students to do even more and chided them for what he perceived as their lack of interest and indifference. He noted: "Notwithstanding our best efforts we always had to fight a general indifference and lack of interest in our student body ... We can never rely on your support" (SUM, March 1923).

In particular he criticised them for doing too little to alleviate the problem of poor whites on their doorstep. Under the heading "Die veragtelikes in ons midde" (The despised in our midst), Verwoerd accused his fellowstudents of not doing much about the poor whites ("armblankes") (SUM, Nov. 1920). He also slammed the "chaotic" affairs of the commission 
appointed to raise funds for the Voortrekkergedenksaal (Voortrekker memorial hall) (SRC, 1923-08-14), which was of some symbolic importance to Afrikaner nationalists such as Verwoerd. He furthermore supported, as SRC chairman, the renaming and relaunching of the student magazine to better represent the student culture, i.e. Afrikaner culture (SS, March 1924).

As chairman of the speakers' forum he took a strong stand on Dingaan's Day (later named the Day of the Covenant), pointing out that the religious and educational aspects ought to be accentuated if the day were to be an Afrikaner volksfees (people's festival) in the true sense of the word (SUM, April 1923). Verwoerd justified the Afrikaner nationalist objectives of the forum as follows: "We want to help underprivileged people (volksgenote) in their legitimate demands for development opportunities and a broader vision. We will uphold (handhaaf)!" (SS, Apr. 1924)

How effective Verwoerd's leadership was cannot be assessed with any accuracy, but his views almost certainly played a role in the founding of a Vrouestudentebond (student women's league), given the fact that its founding chairperson, Betsie Schoombee, was the future Mrs Verwoerd, with whom Verwoerd already had a strong relationship at that stage (Scholtz, 1974:17). It certainly fitted with his views in this regard. This society immediately made an impact by actively educating women students on social and health matters. Yet, an important focus of the Vrouestudentebond (VSB) remained uplifting the "poor classes", as was urged by Verwoerd the previous year (Minutes of VSB, 27.10.1921; VSB annual report, June 1923).

As with all other facets of Stellenbosch student life, the VSB's activities were intertwined with, and part of, the students' devotion to their national identity. They refused, for example, to participate in a fête at the local hospital as the nurses' home was a World War I memorial (VSB, 27.3.1924) and therefore perceived as a symbol of the British empire Verwoerd may not have had a direct hand in this protest, but it clearly echoed his earlier stand vis-à-vis the playing of "God Save the King".

On economic matters the young Verwoerd took a stand consistent with his other Afrikaner nationalist views. Debating the issue of free trade with two visiting students from the University of Oxford, Verwoerd was in devastating form. According to the Cape Times he "rattled off a variety of facts and figures ... maintaining that a policy of protection was not only warranted for South Africa but that it was indispensable" (Scholtz, 1974:22). Echoing the sentiments he held many decades later as prime minister when he led South Africa from the British Commonwealth, Verwoerd stated: 
We advocate the right of every country's government to interfere with its internal or external trade if this is necessary for the welfare of the inhabitants of that country as a whole; we advocate the right of every country to an industrial policy which is best adapted to its own needs (Scholtz, 1974:22).

Could Verwoerd have defended a viewpoint merely for the sake of the debate? Possibly. But it was clearly in agreement with his other views. Furthermore, Verwoerd was not one to take opportunistic stands, as illustrated by his clash with the church body supervising entrance to the Stellenbosch theological seminary of the Dutch Reformed Church. Verwoerd refused to apologise for requesting information about a letter of recommendation, choosing rather to withdraw his application to be admitted to the seminary (Scholtz, 1974:23). This ended his dreams of becoming a church minister.

Verwoerd was, as can be deduced from his economic viewpoints, an isolationist. It would therefore have been somewhat surprising if the Stellenbosch SRC had accepted an invitation in 1922 to participate in the founding of the National Union of Students of South Africa (Nusas). Under Verwoerd's chairmanship, the SRC decided that they were "not inclined to participate in the movement" (SRC, 1922-10-30). At that stage Afrikaner nationalists were preoccupied with building up their own cultural institutions, uplifting their own disadvantaged people and wresting power from those Afrikaners in government who were perceived as sell-outs to British imperialist interests. A number of invitations were again extended, and eventually Stellenbosch relented (in the absence of Verwoerd), sending a delegation to the Nusas founding congress in 1924 (SRC, 1924-08-08). This was the start of many years of fruitful contact between Stellenbosch and other universities until the presence of black students at English-speaking universities led to most Afrikaans universities and university colleges withdrawing from Nusas in the 1930s (Froneman, 1995:175-181).

All this took place within a general Christian ethos in which attending church was a normal part of student life and in which the SRC intervened directly in church affairs (SRC, 1920-03-03; SUM, Nov. 1923). Gambling and dance activities were frowned upon and Bible study groups encouraged. But political, religious and social conservatism could not simply be equated (Froneman, 1995:65). The dynamics of the Stellenbosch student life was much more complicated, although group cohesion was regarded highly. The university was, after all, founded not only to serve Afrikanerdom, but also to form men and women who serve the Lord, founding father Prof. A. Moorrees stated (De Burger, 1918-04-04). 


\section{Conclusions}

This then was the Stellenbosch of Verwoerd's student years. He fitted in perfectly, as was proven by his election as SRC chairman. On campus Verwoerd never caught the eye due to deviant behaviour or views, but attracted attention for his fervour and decisive leadership.

Verwoerd's socio-political views - on British imperialism, racial segregation, the poor white problem, and the survival and development of the Afrikaans language and culture - were influenced by, and have to be understood in terms of, the context within which the survival and development of the Afrikaner nation was the dominant motive (Froneman, 1995:282-292). Verwoerd's vies were clearly informed by his context; likewise he actively participated in creating a particular context.

The question can be asked whether Miller was correct (1993:1) when she identified a transformation in Verwoerd's mind, a "radical break with many of the social and political positions he had previously held"? Furthermore: if Verwoerd the academic really were a different person from Verwoerd the editor, what about Verwoerd the student? In view of the above, the following comments could be put forward:

- Of course Verwoerd could have been an opportunist and a brilliant actor. Any monolithic interpretation of the development of his political social and other views could certainly miss more subtle points However, it is quite possible that Verwoerd refused to take advantage of his position as lecturer to propagate his political views, thereby giving the impression that he later changed his views (Verwoerd 1994). It could also be that Verwoerd merely focused on other issues while he occupied a chair in social work. This would be understandable. But as Miller offers no evidence of Verwoerd being an opportunist, this idea has to be rejected. No inconsistency can be detected looking at Verwoerd the student and Verwoerd the adult editor/politician

- A plausible explanation for Verwoerd's co-operation with Englishspeakers in his years as lecturer could be that he merely rejected English- and Afrikaans-speakers who insisted on placing British interests first. He was perfectly happy to co-operate with Englishspeaking people in as much as they jointly worked, for example, to alleviate the poor white problem. This was totally consistent with the strong views he expressed as a student leader regarding the upliftment of poor whites

- His command of English as student (cf. Scholtz, 1974:21) as well as his firm but cordial letter to the conductor of the Cape Town symphony 
orchestra, indicated his ability and willingness to use English, which hardly suggests an anti-English attitude - even when he was a strongly pro-Afrikaans student. His co-operation with English-speakers in the field of welfare was an extension of this attitude. This also correlates with Verwoerd's conciliatory remarks many years later on accepting the premiership in 1958. In a radio message to the nation, Verwoerd expressed satisfaction about what he perceived as signs of better relations between the two main white language groups Nerwoerd, s.a). He added that he was looking forward to the day when the two language groups would form one volk (people). As a student his focus was, however, on uplifting the Afrikaner.

- The content of his nationalism could have shifted in emphasis during the latter half of the 1930s and early 1940s, i.e. before and during the turbulent World War II years which saw the intimidation of and attacks on anti-war Afrikaner institutions, including the editorial offices of Die Transvaler (Scholtz, 1974:21). But Miller merely alludes to any such changes in Verwoerd's views without referring to the context, or supplying specific evidence to substantiate her "transformation" theory.

In assessing the consistency of the views Verwoerd held as student, lecturer, newspaper editor and politician, it is not difficult to identify a core of Afrikaner nationalist views and a concomitant rejection of British imperialism, as well as his passionate endeavours regarding poor whites and his acceptance of racial segregation as the political "answer" to the racial issue. As such he was simultaneously a (cultural) Afrikaner nationalist and a (white) political nationalist. This was very clear even as a student. As such the notion that Verwoerd radically changed his ideas is mere speculation. For better or for worse, Verwoerd was consistent on major issues.

Unlike Miller's conclusions, Venter's findings (1999) correlate largely with the empirical evidence presented here:

- The young Verwoerd insisted on greater commitment by fellowstudents in the task of uplifting and educating fellow-whites. Whether this was a top-down approach (as Venter detected in the later Verwoerd) is not apparent, but possible. Verwoerd clearly had a vision of what he believed needed to be done and admonished fellowstudents to follow suit.

- Verwoerd and his fellow-students sought security in keeping apart from outside non-Afrikaner influences. Contact with other (nonAfrikaans) students were at first rejected and the prevention of any 
H.F. Verwoerd's student years - cradle of his political career and thought

possible friction between people of different races (e.g. in the local cinema) was done by insisting on the exclusion of non-whites. Even a black academic (from the USA) was not acceptable as speaker. This is clearly a forerunner of government policies under prime minister Verwoerd, who, inter alia, refused to accept blacks in visiting international sports teams. Underlying the students' actions could well have been the notion that justice equalled the protection of ethnic identity, as noticed by Venter in the later Verwoerd.

- Whether Verwoerd's perceived near pietism was partly or wholly a result of his experiences as student is debatable. Prof. Moorrees' Calvinistic Stellenbosch University consecration speech in 1918 was Calvinistic in as much as it linked belief in God to day-to-day actions, but this was not necessarily practised by all students. But as a committed Christian who initially prepared himself for the ministry, the young Verwoerd did link his religious convictions directly to the service of his people (cf. Froneman, 1995:101). He was also versed in Reformed theology (Scholtz, 1974: 23).

It is clear that any interpretations offered to explain Verwoerd's political mind must take cognisance of Verwoerd the student. Apart from childhood influences, which were also significant (Scholtz, 1974:8-15; Verwoerd, 1990:2-6), his student years at Stellenbosch may well have been definitive in the shaping or cementing of Verwoerd's character and future political career and thought. Although there is not a huge amount of empirical evidence on Verwoerd's views as a student (inter alia because Verwoerd did not keep letters which could have been illuminating), the available evidence forms a coherent picture. To reject the validity of his stated views and those he subscribed to via decisions he was party to, would be to reject the only evidence at hand. At the very least the context in which Verwoerd functioned as a student is an important indicator of the influences which helped to shape his mind, even if he did not subscribe to each and every aspect of Afrikaner nationalism as it manifested itself at Stellenbosch.

One can therefore conclude that, on the one hand, his views as a young man were informed by the Afrikaner nationalist Stellenbosch of his student years; on the other hand, he actively participated and helped form that very context. This is of some significance in trying to understand Verwoerd.

\section{Bibliography}

BOOYENS, B. 1969. Die lewe van D.F. Malan. Kaapstad : Tafelberg

BURGERS, M.P.O. 1939. Die mens Langenhoven. Kaapstad : Nasionale Pers 
DAVENPORT, T.R.H. 1988. South Africa: A modern history. Southern : Bergviei, South Africa.

De Burger, 1918-04-04.

Die Burger, 1924-06-19.

DU TOIT, P.S. \& VENTER, G.S. 1966. Die Universiteit van Stellenbosch word 'n werklikheid. (In Thom, H.B., red Stellenbosch 1866-1966. Honderd jaar hoër onderwys. Kaapstad : Nasionale Boekhandel. p. 62-70.)

DU TOIT, P.S 1966. Ander akademiese bedrywighede. (In Thom, H.B., red. Stellenbosch 1866-1966. Honderd jaar hoër onderwys. Kaapstad : Nasionale Boekhandel. p. 173-183.)

DU TOIT, P.S. 1966. Die Fakulteit van Lettere en Wysbegeerte. (In Thom, H.B., red. Stellenbosch 1866-1966. Honderd jaar hoër onderwys. Kaapstad : Nasionale Boekhandel. p. 71-97.)

EYSSEN, S. 1964. US se eerste twee studentetoere Matieland, Aug.

FRONEMAN, J.D 1995. Die kommunikasie van Afrikanernasionalisme deur Stellenbosse studente, 1902-1948. Potchefstroom : PU VIR CHO. (Ph.D.proefskrif.)

GERICKE, M. 1977. Die sangbelewing van die Stellenbosse student. Stellenbosch : Universiteit van Stellenbosch. (BA Honneurs.)

HUGO, A 1966. Studentelewe, 1866-1939. (In Thom, H.B., red Stellenbosch 18661966. Honderd jaar hoër onderwys. Kaapstad: Nasionale Boekhandel. p. 263358.)

KANNEMEYER, J C. 1995. Langenhoven. 'n Lewe Kaapstad: Tafelberg

KAPP, P. 1975. Ons volksfeeste Kaapstad: Tafelberg.

MALHERBE, F.E.J. 1977. Agter die oomblik. Johannesburg : Perskor

MALHERBE, M. 1979. Amateurtoneel. (In Smuts, F., red Stellenbosch drie eeue. Stellenbosch : Town Council, Stellenbosch. p. 401-403.)

MEIRING, P. 1974. Jan Smuts die Afrikaner. Kaapstad: Tafelberg

MILLER, R.B. 1993. Science and society in the early career of H.F. Verwoerd Journal of Southern African Studies, 19(4):1-29.

MULLER C.F.J. 1990. Sonop in die Suide. Kaapstad: Nasionale Boekhandel.

PRETORIUS G. 1959. Man van die daad - 'n biografie van Bruckner de Villiers Kaapstad : HAUM

ROTHMAN, A, MURRAY, A., SCHLENGEMAN, E.A. \& BUHR, J. 1924. Retrospectumus - 'n weerspieëling van die laaste vyftig jaar, 1874-1924. Stellenbosch : Universiteits-Debatsvereniging.

SCHOLTZ, G.D. 1974 Dr. Hendrik Frensch Verwoerd, 1901-1966. Johannesburg : Perskor

SLABBERT, S 1992. Die veranderlike konstantes van die Afrikaanse vrouetydskrif. Tydskrif vir Geesteswetenskappe, 32(3):193-208

SRC

see Minutes of Student Representative Council of the University of Stellenbosch,

SS 1918-24.

see Stellenbosch Student, 1923-24

SUM

see Stellenbosch University Magazine, 1918-1923.

VAN BLERK, B.E. 1986. Die musieklewe van Stellenbosch 1679-1950. Stellenbosch : Universiteit of Stellenbosch. (Ph.D.-proefskrif.)

VENTER, J.J 1999. H.F. Verwoerd: Foundational aspects of his thought. Koers, 64(4):415-442. 
VERWOERD, H.F s a. Recording of Verwoerd's radio message, released by the National Youth League of Transvaal in conjunction with the SABC and Brigadiers. Johannesburg.

VERWOERD, W.J. 1990. Dr. H.F. Verwoerd: vegter vir vryheid. Pretoria : Sabra

VERWOERD, W.J. 1994. Hendrik Verwoerd was alles behalwe 'n pragmatis. Die Burger, Nov. 3

VSB VSB

see Annual report of the Vrouestudentebond, June 1923

see Minutes of the Vrouestudentebond, 1921; 1924

WIID, J.A. 1973. Weeropbou. (In Kruger, D W, red. Geskiedenis van Suid-Afrika Kaapstad : Nasou. p. 434-462.)

\section{Kernbegrippe:}

Afrikanernasionalisme politieke denke van Verwoerd

Stellenbosse studentelewe

Verwoerd

\section{Key concepts:}

Afrikaner nationalism

political thought of Verwoerd

Stellenbosch student life

Verwoerd 